Article

\title{
An Electrochemical Immunosensor for Sensitive Detection of the Tumor Marker Carcinoembryonic Antigen (CEA) Based on Three-Dimensional Porous Nanoplatinum/Graphene
}

\author{
Aihua Jing ${ }^{1}$, Qiong $X u^{1}$, Wenpo Feng ${ }^{1}$ and Gaofeng Liang ${ }^{2, *}$ \\ 1 School of Medical Technology and Engineering, Henan University of Science and Technology, \\ Luoyang 471023, China; aihuaj@haust.edu.cn (A.J.); xuqiong@stu.haust.edu.cn (Q.X.); \\ fwp238@haust.edu.cn (W.F.) \\ 2 Medical College, Henan University of Science and Technology, Luoyang 471023, China \\ * Correspondence: Lgfeng990448@haust.edu.cn; Tel.: (+86)-0379-64162573
}

Received: 21 June 2020; Accepted: 30 June 2020; Published: 3 July 2020

\begin{abstract}
Carcinoembryonic antigen (CEA) is an important broad-spectrum tumor marker. The quantitative detection of a low concentration of CEA has important medical significance. In this study, three-dimensional porous graphene-oxide-supported platinum metal nanoparticles (3DPt/HGO) composites were prepared by a wet chemical method and modified on an electrode with enhanced conductivity, a large surface area, and good adsorption of immobilizing antibodies $\left(A b_{1}\right)$. Horseradish peroxidase (HRP)-functionalized Au nanoparticles were fabricated to label the secondary antibodies $\left(\mathrm{Ab}_{2}\right)$. The proposed immunosensor showed a good linear relationship in the range of $0.001-150 \mathrm{ng} / \mathrm{mL}$ for CEA and a detection limit of $0.0006 \mathrm{ng} / \mathrm{mL}$. The immunosensor had high sensitivity, good stability and reproducibility, and has great application prospects for the clinical diagnosis of cancer.
\end{abstract}

Keywords: carcinoembryonic antigen (CEA); three-dimensional porous graphene; platinum (Pt); electrochemical immunosensor; tumor marker; detection

\section{Introduction}

Carcinoembryonic antigen (CEA), an important broad-spectrum tumor biomarker, is used as an efficient prognostic indicator in the early clinical diagnosis and disease prevention of pancreatic cancer [1,2], colorectal cancer [3,4], breast cancer [5,6], lung cancer [7,8], and gastric cancer [9-11]. The sensitive detection of low levels of CEA in serum is of great clinical significance in assessing tumor status and therapeutic efficiency, as well as in the early clinical diagnosis of tumor. To date, different strategies have been used to measure CEA, such as radioimmunoassay [12], chemiluminescence analysis [13], enzyme-linked immunosorbent assay [14,15], and electrochemistry [16,17]. Among these methods, electrochemical immunosensors $[18,19]$ have attracted considerable attention due to their distinct advantages, such as high selectivity, fast response, low sample requirements, miniaturization, and excellent sensitivity [20-23]. Nonetheless, new immunosensors fabricated with nanomaterials that have excellent performance for the quick and simple detection of CEA with high sensitivity and selectivity are still urgently needed in the medical field.

The signal amplification system is vital to improving detection sensitivity and selectivity. Generally, it contains two parts: a platform and a label. The platform of the designed immunosensor is the first key part in the quantitative assay of CEA. It should have a good capacity to immobilize more antibodies and enhance the electron transfer. Therefore, various nanomaterials with good electron 
transfer ability, biocompatibility, and large specific surface area are suitable for the immobilization [24]. Three-dimensional graphene interfacial materials have been widely used as supporting materials in electrochemical biosensors because the good electrical conductivity [25], thermal conductivity [26], and biocompatibility [27] of graphene can enable fast electron transfer and rapid mass transport with large surface areas [28]. Typically, graphene oxide with nanohole macrostructures exhibits improved electron transfer dynamics compared to those of non-holey graphene oxide [29]. Three-dimensional porous graphene structures serving as electrode materials are expected to show improved electron transfer and mass transport during the electrochemical detection of tumor markers. Furthermore, anchoring nanoscale noble metal particles onto specific supports such as 3D graphene can improve more highly active centers on the 3D noble metal/graphene composite [30]. Pt nanoparticles have been used as the substrate material for the incubation of the capture antibody $\left(A b_{1}\right)$ in immunosensors. Pt nanoparticles can aggregate due to their small particle size and large electrochemical active area. They were decorated on a support material with high surface area and high electrochemical stability to keep their activity [31]. Pt nanoparticles functionalized with various graphene structures, for example, porous Pt/ionic liquid/graphene [32], PtPd/nitrogen/graphene [33], NiAuPt/graphene [22], porous platinum/PdPt nanocages [34], and gold/bienzyme/platinum/graphene [35] have been immobilized on electrodes to accelerate the electron transfer and provide a superior microenvironment for capturing more antibody $\left(\mathrm{Ab}_{1}\right)$, thereby improving the sensitivity of the CEA immunosensors. There is still great interest in and need for developing new 3D graphene and Pt nanoparticle composites. Here, three-dimensional porous graphene-oxide-supported platinum metal nanoparticles (3DPt/HGO) composites, with enhanced conductivity and large surface areas, are modified on an electrode in order to immobilize $A b_{1}$ and improve the sensitivity of the electrochemical immunosensor.

The label of the designed immunosensor is the second key part of the quantitative assay of CEA. It should have good catalytic activity itself or can act as an electroactive substance in detection [21]. Noble metal nanoparticles often work as electroactive substances in electrochemical immunosensors due to their good biocompatibility, high anti-interference capability and excellent electrical conductivity [36]. Here gold nanoparticles were used in this immunosensor to provide a suitable interface to anchor more $\mathrm{Ab}_{2}$ to amplify electrochemical signals.

In this work, a sandwich-type electrochemical immunosensor comprised of a 3D composite of $\mathrm{Pt}$ nanoparticles deposited on 3D graphene oxide with nanopores was designed for the electrochemical detection of the tumor biomarker CEA. Figure 1 displays a graphical illustration of the fabrication and detection process of the sandwich-type immunoassay. 3DPt/HGO with high conductivity and large active surface area was used as the substrate material of the immunosensor for the capture of $A b_{1}$. Gold nanoparticles were used as signal tags to improve the sensitivity of the immunosensor by capturing the secondary antibody $\left(\mathrm{Ab}_{2}\right) / \mathrm{HRP}$ (horseradish peroxidase). The signal of the proposed immunosensor was linear from 0.001 to $150 \mathrm{ng} / \mathrm{mL}$ CEA and had a low detection limit of $0.0006 \mathrm{ng} / \mathrm{mL}$. The developed immunosensor was tested in human serum samples for CEA detection. The obtained satisfactory recovery of the ultrasensitive immunosensor indicated a potential practical application in clinical diagnostics. 


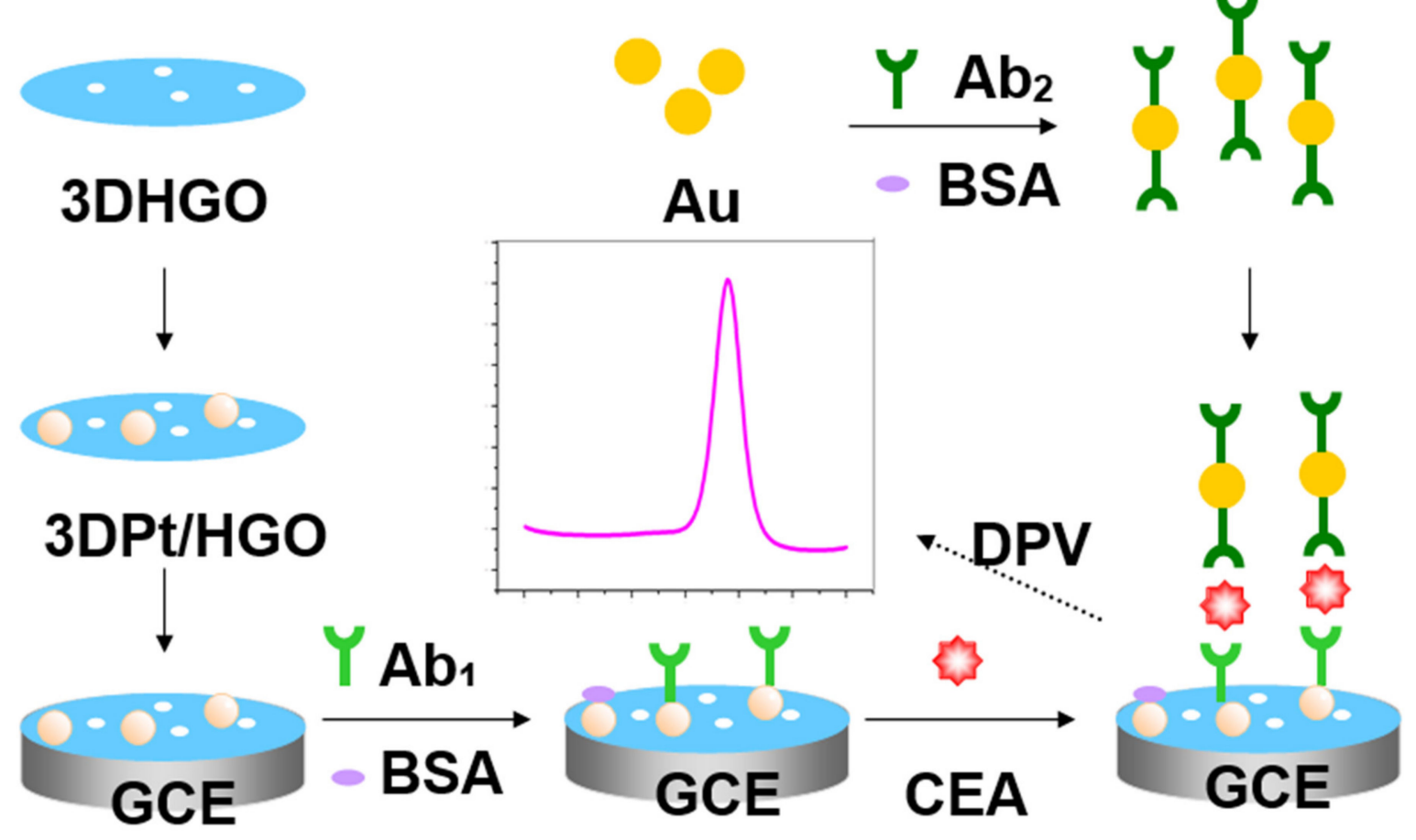

Figure 1. The schematic illustration of the fabrication process of the carcinoembryonic antigen (CEA) immunosensor. $\mathrm{Ab}_{1}$ : capture antibody; $\mathrm{Ab}_{2}$ : secondary antibody; 3DPt/HGO: 3D porous graphene-oxide-supported platinum metal nanoparticles; GCE: glass carbon electrode.

\section{Experimental Sections}

\subsection{Instruments and Reagents}

A JEOL JSM-7800F field-emission scanning electron microscope (FE-SEM) was used to characterize the morphologies and energy-dispersive spectrometry (EDS) of the product. CEA, alpha-fetoprotein (AFP), HRP-conjugated rabbit anti-mouse IgG, bovine serum albumin (BSA), and chloroplatinic acid were purchased from Shanghai Sangon Bioengineering Co. (Shanghai, China). The mouse-derived CEA antibody was purchased from Linc-Bio Science Co. Ltd. (Shanghai, China). L-Cysteine, glucose, vitamin C, and L-glutamine were purchased from Tianjin Fengchuan Chemical Reagent Technology Co. (Tianjin, China). Phosphate buffer solutions (PBS, pH 7.4) were made from $0.1 \mathrm{M} \mathrm{Na}_{2} \mathrm{HPO}_{4}$ and $0.1 \mathrm{M} \mathrm{KH}_{2} \mathrm{PO}_{4}$ solutions. All chemicals and solvents used were of analytical grade. Double-distilled water was used. The human serum was collected and treated as follows: the blood was extracted and put into a centrifuge tube, then centrifuged for $5 \mathrm{~min}$ at $1000 \mathrm{rpm}$ at low temperature $\left(4{ }^{\circ} \mathrm{C}\right)$. The supernatant (serum) was carefully taken out and frozen for future use.

\subsection{Preparation of $3 D$ Porous Graphene Oxide (3DHGO)}

The GO and HGO were prepared by a modified Hummer's method, as reported by our group [27]. The 3DHGO was prepared by a hydrothermal method. Briefly, $10 \mathrm{~mL}$ of HGO solution $(2 \mathrm{mg} / \mathrm{mL})$ was sealed and maintained at $180{ }^{\circ} \mathrm{C}$ for half a day. Then, at room temperature, $\mathrm{HI}(55 \%)$ was added and heated at $100{ }^{\circ} \mathrm{C}$ for $3 \mathrm{~h}$. After that, the obtained results were dialyzed in ultrapure water for 2 days [37].

\subsection{Preparation of $3 D P t / H G O$ Composites}

The 3DPt/HGO composites were prepared by a modified wet chemical method. Typically, $0.5 \mathrm{mg} / \mathrm{mL}$ of 3DHGO was first thoroughly ultrasonicated for $30 \mathrm{~min}$. Then, $9.2 \mathrm{~mL}$ of $10 \mathrm{mM}$ $\mathrm{H}_{2} \mathrm{PtCl}_{6} \cdot 6 \mathrm{H}_{2} \mathrm{O}$ was added to the above $3 \mathrm{DHGO}$ suspension at $0{ }^{\circ} \mathrm{C}$ and continuously stirred for $30 \mathrm{~min}$. 
The reaction mixture was further purified by centrifugation at $12,000 \mathrm{rpm}$ for $30 \mathrm{~min}$ and washed 3-4 times with deionized water. Finally, the solution of 3DPt/HGO nanocomposites was obtained [38].

\subsection{Preparation of $A b_{2}-H R P / A u$ Bioconjugate}

The gold nanoparticles were first synthesized according to a published method [39]. The solutions of gold nanoparticles $(2.0 \mathrm{mg} / \mathrm{mL}, 1 \mathrm{~mL})$ and $\mathrm{Ab}_{2}(10 \mu \mathrm{g} / \mathrm{mL}, 1 \mathrm{~mL})$ were well-mixed and stirred for $24 \mathrm{~h}$ at $4{ }^{\circ} \mathrm{C}$. Then, $0.1 \%$ BSA was added to block the remaining active sites of the gold nanoparticles. After centrifugation, the resulting $\mathrm{Ab}_{2}-\mathrm{HRP} / \mathrm{Au}$ bioconjugate was dispersed in $1 \mathrm{~mL}$ PBS solution and stored at $4{ }^{\circ} \mathrm{C}$.

\subsection{Fabrication of the Electrochemical Immunosensor}

Figure 1 shows a schematic fabrication of the electrochemical immunosensor. A glass carbon electrode (GCE, diameter $3 \mathrm{~mm}$ ) was polished with 0.3 - and $0.05-\mu \mathrm{m}$ alumina slurry and cleaned by an ultrasonic cleaner with $\mathrm{HNO}_{3}$ (1:1), acetone, anhydrous ethanol, and secondary distilled water. The clear GCE was dried at room temperature. Following this, $10 \mu \mathrm{L}$ of $3 \mathrm{DPt} / \mathrm{HGO}$ nanocomposite was dropped on the GCE surface, and then $5 \mu \mathrm{L}$ of anti-CEA was dropped evenly on the 3DPt/HGO nanocomposite surface. The electrode was cleaned with pH 7.4 PBS and incubated in a refrigerator for $13 \mathrm{~h}$. After this, the 3DPt/HGO was immersed in $1.0 \mathrm{wt} \% \mathrm{BSA}$ solution for $35 \mathrm{~min}$ at $37^{\circ} \mathrm{C}$ to block the remaining active sites in order to avoid non-specific adsorption. Then, the immunosensor was cleaned with PBS and dried using a high-purity nitrogen steam. Subsequently, the sensor was incubated in solutions with various concentrations of CEA for $40 \mathrm{~min}$ at $37^{\circ} \mathrm{C}$, washed with PBS solution, and dried under a steam of nitrogen. Finally, the immunosensor was immersed in $\mathrm{Ab}_{2}-\mathrm{HRP} / \mathrm{Au}$ solution prepared as in Section 2.4. for the sandwich immunoreaction. After cleaning with $0.01 \mathrm{M}$ PBS, the immunosensor was dried using nitrogen gas.

\subsection{Electrochemical Detection}

A CHI660E electrochemical workstation (Shanghai Chenhua Instrument Co., Ltd, Shanghai, China) recorded all the electrochemical detections with a three-electrode system containing a platinum auxiliary wire, a modified GCE, and a saturated calomel reference. The solutions were degassed with nitrogen to remove $\mathrm{O}_{2}$. Cyclic voltammetry (CV), differential pulse voltammetry (DPV), and electrochemical impedance spectroscopy (EIS) were carried out in the solution (0.1 M PBS $(\mathrm{pH} 7.4)+1 \mathrm{mM} \mathrm{Fe}(\mathrm{CN})_{6}{ }^{3-} /{ }^{4-}$ $(1: 1)+0.1 \mathrm{M} \mathrm{KCl})$.

\section{Results and Discussion}

\subsection{Characterization of Materials}

Figure 2 shows the SEM of 3D Pt/HGO composites with different magnifications and the corresponding EDS. From the SEM images of Figure 2A, it can be seen that 3DHGO had a dense pore structure, and the pore size was mainly between the nanometer and micron size. Figure $2 \mathrm{~B}$ shows that $\mathrm{Pt}$ nanoparticles grew uniformly on 3DHGO; the size was uniform and the particles were small. More importantly, the dispersion of $\mathrm{Pt}$ particles was more uniform and there was little obvious agglomeration. The formation of Pt nanoparticles on the surface of HGOs might be due to the electrostatic interactions of the delocalization $\pi-\pi$ bonds between graphenes and the charged Pt nanoparticles, indicating the successful assembly of Pt nanoparticles on HGOs [40]. The main co-existing elements including $\mathrm{C}$ and $\mathrm{Pt}$ were obvious for the 3DPt/HGO composite (Figure 2D). 


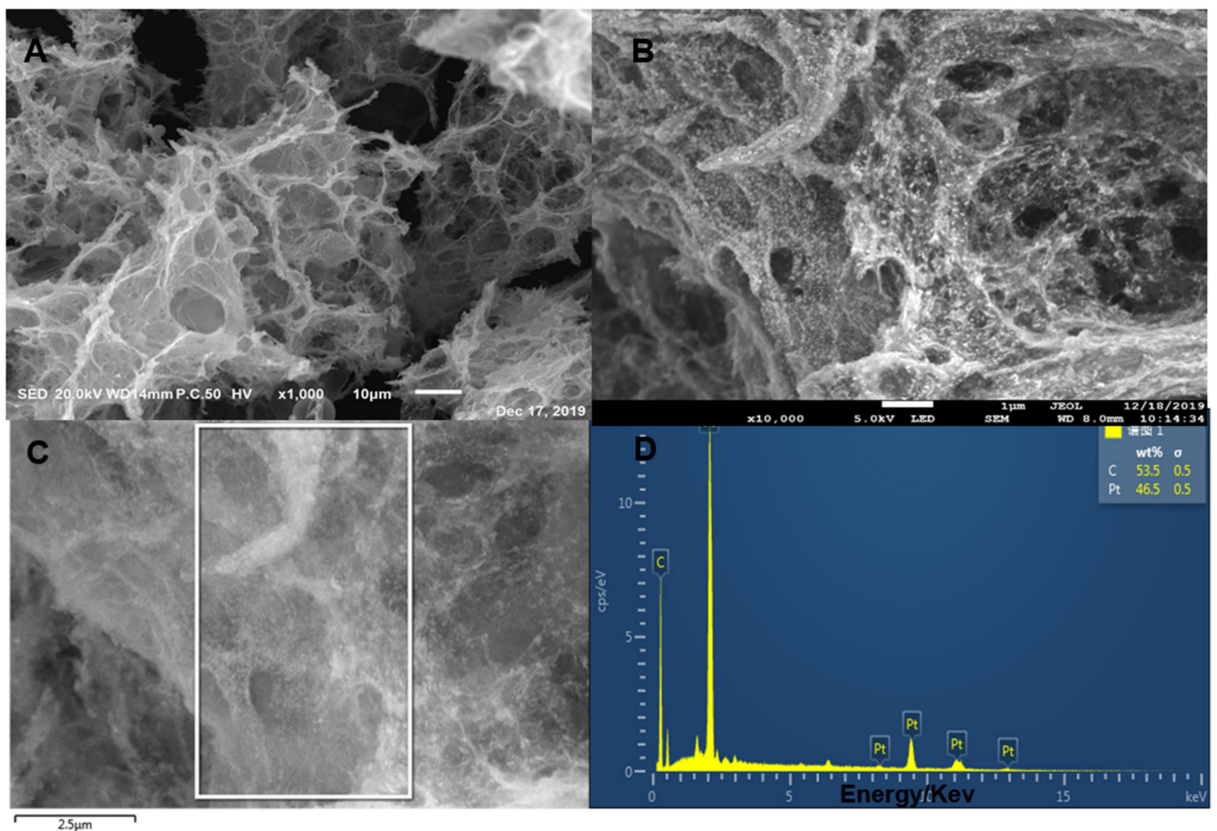

Figure 2. Scanning electron microscope (SEM) images at low (A) and high (B) magnifications of 3DPt/HGO composite, and an SEM image (C) with the corresponding energy-dispersive spectrometry (EDS) (D).

\subsection{Electrochemical Behavior of Modified Electrodes}

$\mathrm{CV}$ and EIS are common electrochemical methods to examine electrode surface modification. Figure $3 \mathrm{~A}$ shows the $\mathrm{CV}$ s of $\mathrm{Fe}(\mathrm{CN})_{6}{ }^{3-} / \mathrm{Fe}(\mathrm{CN})_{6}{ }^{4-}$ at the bare GCE (curve a), 3DPt/HGO/GCE (curve b), $\mathrm{Ab}_{1} / 3 \mathrm{DPt} / \mathrm{HGO} / \mathrm{GCE}$ (curve c), BSA/Ab $1 / 3 \mathrm{DPt} / \mathrm{HGO} / \mathrm{GCE}$ (curve d), CEA/BSA/Ab $1 / 3 \mathrm{DPt} / \mathrm{HGO} / \mathrm{GCE}$ (curve e), and $\mathrm{Ab}_{2} / \mathrm{CEA} / \mathrm{BSA} / \mathrm{Ab}_{1} / 3 \mathrm{DPt} / \mathrm{HGO} / \mathrm{GCE}$ (curve $\mathrm{f}$ ), respectively. It can be seen from Figure $3 \mathrm{~A}$ that the 3DPt/HGO/GCE redox peak current was higher than that of the bare GCE, which means that 3DPt/HGO/GCE showed better charge transfer performance than bare GCE. This was due to the use of the highly porous material 3DPt/HGO, which can increase the electroactive area of the electrode, resulting in a higher redox current. When the electrodes were sequentially modified with $\mathrm{Ab}_{1}, \mathrm{BSA}$, $\mathrm{CEA}$, and $\mathrm{Ab}_{2}$, the peak current gradually decreased, which was attributed to the non-conductivity of $\mathrm{Ab}_{1}, \mathrm{BSA}, \mathrm{CEA}$, and $\mathrm{Ab}_{2}$ molecules. The modification of these insulative molecules on the electrode surface hindered the electron transfer, which resulted in a decrease of the redox peak currents.
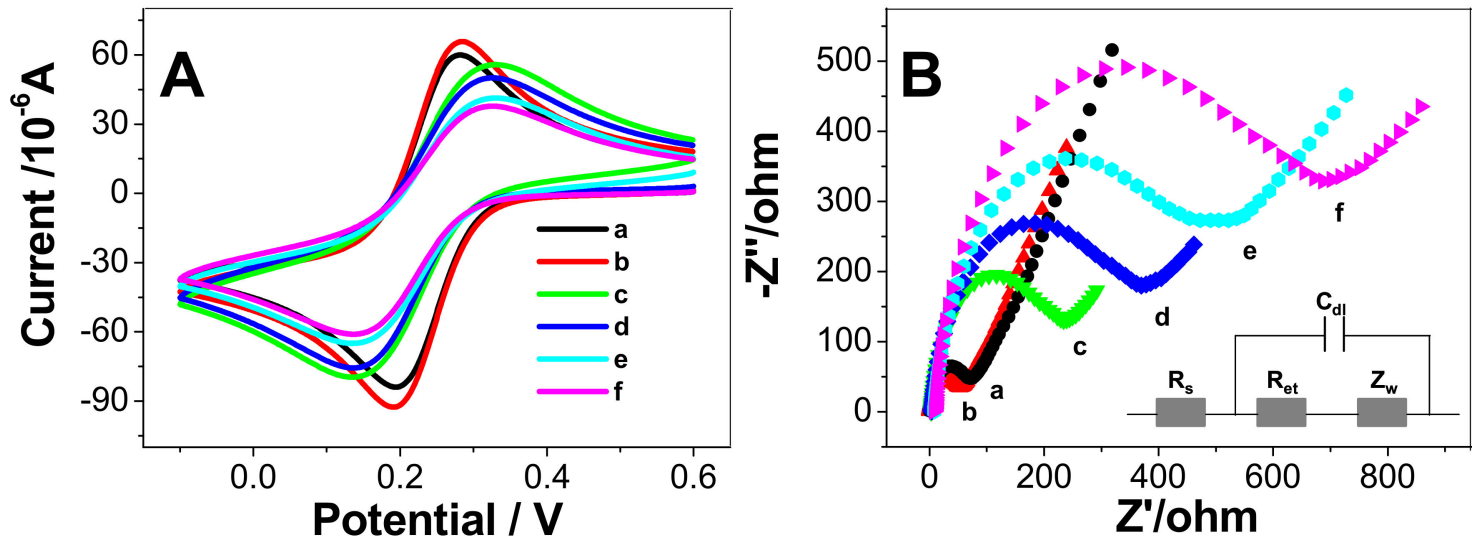

Figure 3. (A) Cyclic voltammetry (CVs) and (B) Nyquist plots of bare GCE (a), 3DPt/HGO/GCE (b), $\quad \mathrm{Ab}_{1} / 3 \mathrm{DPt} / \mathrm{HGO} / \mathrm{GCE} \quad$ (c), $\mathrm{BSA} / \mathrm{Ab}_{1} / 3 \mathrm{DPt} / \mathrm{HGO} / \mathrm{GCE}(\mathrm{d}), \mathrm{CEA} / \mathrm{BSA} / \mathrm{Ab}_{1} / 3 \mathrm{BPt} / \mathrm{HGO} / \mathrm{GCE}(\mathrm{e})$, and $\mathrm{Ab}_{2} / \mathrm{CEA} / \mathrm{BSA} / \mathrm{Ab}_{1} / 3 \mathrm{DPt} / \mathrm{HGO} / \mathrm{GCE}$ (f) in $0.10 \mathrm{M} \mathrm{KCl}$ containing $2 \times 10^{-3} \mathrm{M} \mathrm{K}_{3}\left[\mathrm{Fe}(\mathrm{CN})_{6}\right] / \mathrm{K}_{4}\left[\mathrm{Fe}(\mathrm{CN})_{6}\right]$. Inset is the equivalent circuit. 
Figure 3B shows the EIS of the electrode at each assembly step. The impedance spectra include two parts: a semicircle portion and a linear portion. The former represents the electron transfer process and the latter corresponds to the diffusion process. The semicircle diameter equals the electron transfer resistance, $R_{\text {et }}$. For the bare GCE, it showed a $R_{\text {et }}$ value of $95 \Omega$. After the electrode was modified with 3DPt/HGO on the surface, a lower resistance (the smaller-diameter semicircle) was shown, which is attributed to the fact that the good conductivity of the 3DPt/HGO has a lower electron transfer resistance than bare GCE. When $\mathrm{Ab}_{1}$ (c), BSA (d), CEA (e), and $\mathrm{Ab}_{2}(\mathrm{f})$ were adsorbed on the electrode step by step, the $R_{\text {et }}$ value increased gradually to $267 \Omega, 387 \Omega, 506 \Omega$, and $695 \Omega$, respectively. This was due to the poor conductivity of these molecules blocking the electron transfer on the redox probe. The results were consistent with previous studies [22,41,42]. These EIS results were consistent with the CV curves shown in Figure 3A. The above experimental results indicate that the immunosensor was successfully fabricated.

We ran a control experiment that involved $\mathrm{Ab}_{2} / \mathrm{Au} \mathrm{NPs}$ with and without CEA immobilized onto the electrode surface. In the absence of CEA, a very small signal was shown. When there was $0.1 \mathrm{ng} / \mathrm{mL}$ CEA, a high signal was shown. We think this was due to the fact that no sandwich immunoassay was formed without the CEA.

\subsection{Optimization of Experimental Conditions}

To obtain the optimal performance of the immunoassay, experimental conditions such as the $\mathrm{pH}$ value, the volume of 3DPt/HGO, and the incubation time were studied. The $\mathrm{pH}$ value is the most influential factor in these experiments, because an acidic or alkaline solution can affect the antigen-antibody linkage and the activity of biomolecules. Figure $4 \mathrm{~A}$ shows that when the $\mathrm{pH}$ value of PBS changed from 6.8 to 7.4, the current responses of the proposed immunosensor increased. When the $\mathrm{pH}$ values of PBS changed from 7.4 to 8.0, the current responses of the proposed immunosensor decreased. The highest current was reached at $\mathrm{pH}$ 7.4. This is consistent with the $\mathrm{pH}$ of body fluid, meaning that antigens and antibodies will maintain their bioactivity at a near-neutral $\mathrm{pH}$. Therefore, the $\mathrm{pH}$ of 7.4 was used for the PBS solution in our further research.
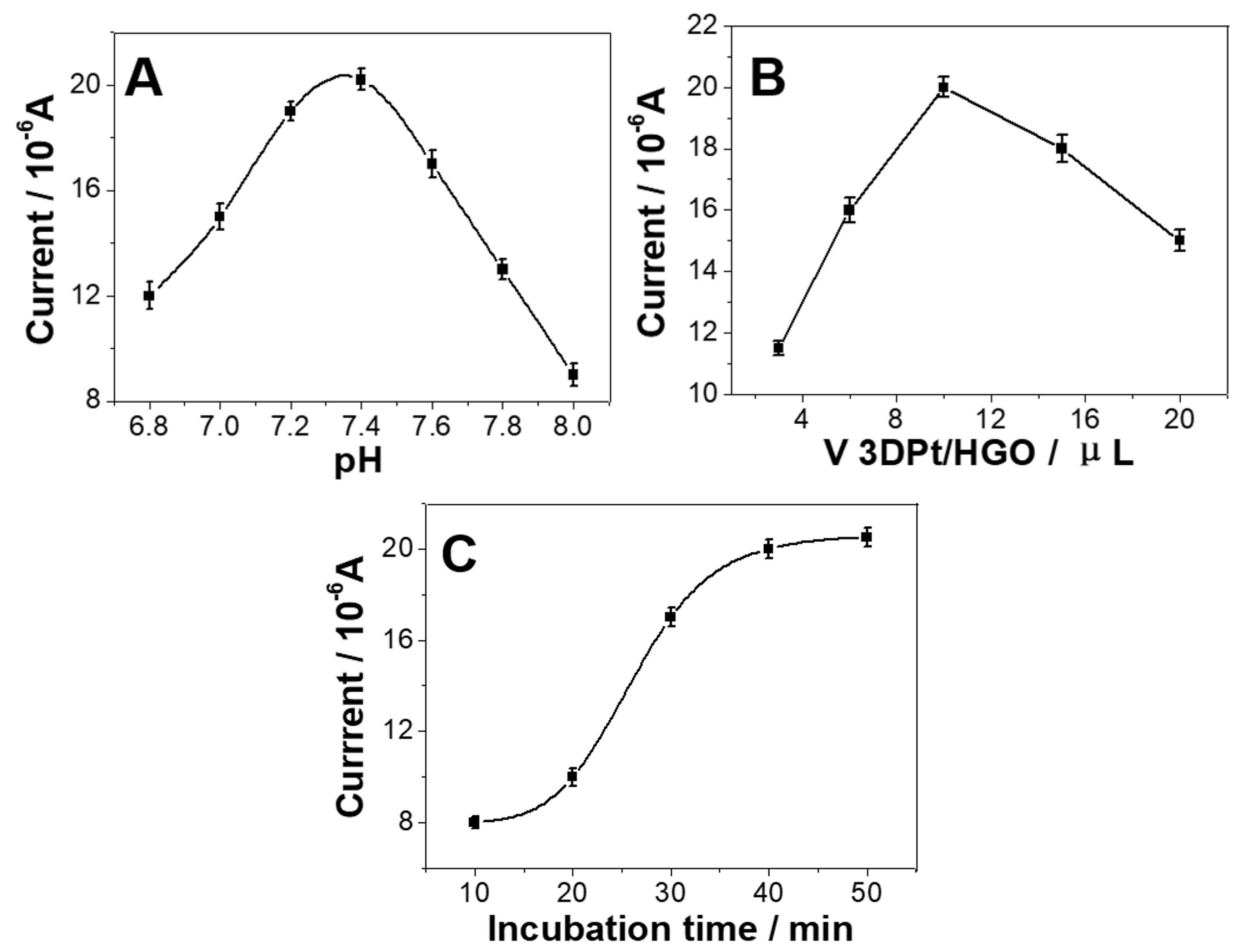

Figure 4. Effect of (A) $\mathrm{pH},(\mathbf{B})$ the volume of 3DPt/HGO, and (C) the incubation time on the differential pulse voltammetry (DPV) response during the detection of CEA. 
As illustrated in Figure 4B, when $3 \mu \mathrm{L}, 6 \mu \mathrm{L}$, and $10 \mu \mathrm{L}$ of 3DPt/HGO was modified on the electrode, it was found the that the immunosensor had a higher current response when detection of CEA (10 ng/mL) compared with the volume of 3Dpt/HGO used on the electrode of $3 \mu \mathrm{L}$ or $6 \mu \mathrm{L}$. This suggests that more 3DPt/HGO can load a higher amount of $\mathrm{Ab}_{1}$. However, when $15 \mu \mathrm{L} / 20$ $\mu \mathrm{L} 3 \mathrm{DPt} / \mathrm{HGO}$ was modified on the electrode, the peak currents of the immunosensors decreased. This might mean that too much 3DPt/HGO modified on the immunosensor's surface will block the electron transfer. Therefore, $10 \mu \mathrm{L}$ 3DPt/HGO was used for the fabrication of the immunosensors.

The influence of the incubation time on the immunosensor was also investigated. The immunosensor was incubated in CEA solutions for various longer times at $37^{\circ} \mathrm{C}$. Figure $4 \mathrm{C}$ shows that longer incubation time led to higher current responses for the detection of CEA. After $40 \mathrm{~min}$, the DPV current tended to not increase any further, indicating that the captured CEA antigen reached saturation. Therefore, $40 \mathrm{~min}$ incubation time was chosen for the further experiments $[43,44]$.

\subsection{Sensor Response Characteristics}

Under the optimized conditions, different concentrations of CEA were measured by immunosensors, and their DPV signals were recorded. The peak current of the $\mathrm{CEA} / \mathrm{BSA} / \mathrm{Ab}_{1} / 3 \mathrm{DPt} / \mathrm{HGO}$ can be seen in Figure $5 \mathrm{~A}$.
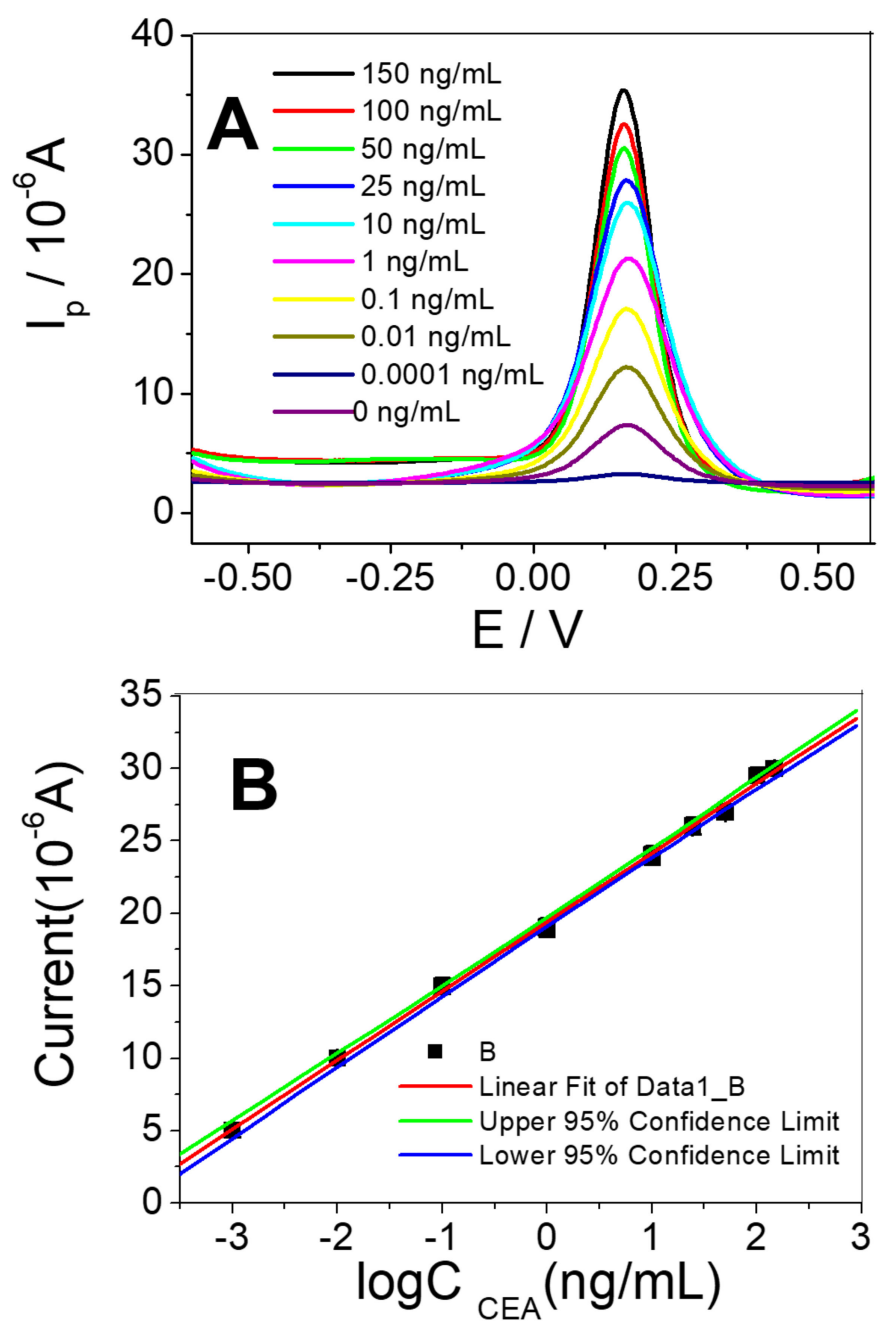

Figure 5. (A) DPV response of the immunosensor to different concentrations of CEA (top-down: 150, $100,50,25,10,1,0.1,0.01,0.001,0 \mathrm{ng} / \mathrm{mL}$ ); (B) Calibration curve of the immunosensor to different concentrations of CEA. 
The immunosensor's response increased gradually with the increase of CEA concentration. The calibration plots (Figure 5B) display a good linear relationship between the peak currents and the log concentration of analytes in the range of $0.001 \mathrm{ng} / \mathrm{mL}$ to $150 \mathrm{ng} / \mathrm{mL}$ for CEA. The linear response obtained between the peak current $(\triangle \mathrm{I})$ and $\log \mathrm{C}_{\mathrm{CEA}}$ concentration was $\triangle \mathrm{I}(\mu \mathrm{A})=19.4342+4.7782 \log \mathrm{C}_{\mathrm{CEA}}(\mathrm{ng} / \mathrm{mL})$. The correlation coefficient was 0.9993 and the limit of detection was $0.0006 \mathrm{ng} / \mathrm{mL}$. Based on these results, it is concluded that the proposed immunosensor achieved a satisfactory detection limit and had a logarithmic linear response. Compared with most of the sensors previously developed for CEA detection, as summarized in Table 1, this immunosensor exhibited a similar detection limit and a linear range.

Table 1. Comparison of the response characteristics of different modified electrodes.

\begin{tabular}{ccccc}
\hline Electrode & Detection Range & Detection Limit & Method & Ref. \\
\hline $\begin{array}{c}\text { Pt/ionic liquid/graphene } \\
\text { Nitrogen-doped } \\
\text { graphene/PtPd }\end{array}$ & $0.001 \mathrm{fg} / \mathrm{mL}-1 \mathrm{ng} / \mathrm{mL}$ & $0.0003 \mathrm{fg} / \mathrm{mL}$ & ECL & {$[32]$} \\
$\begin{array}{c}\text { NiAuPt nanoparticles on } \\
\text { graphene }\end{array}$ & $5 \mathrm{fg} / \mathrm{mL}-50 \mathrm{ng} / \mathrm{mL}$ & $2 \mathrm{fg} / \mathrm{mL}$ & A.C. impedance & {$[33]$} \\
$\begin{array}{c}\text { Platinum nanoparticles } \\
\text { /PdPt nanocages }\end{array}$ & $0.001-100 \mathrm{ng} / \mathrm{mL}$ & $0.27 \mathrm{pg} / \mathrm{mL}$ & DPV & {$[22]$} \\
$\begin{array}{c}\text { Graphene/platinum } \\
\text { nanoparticles } \\
\text { 3DPt/HGO }\end{array}$ & $0.05-200 \mathrm{ng} / \mathrm{mL}$ & $1.4 \mathrm{pg} / \mathrm{mL}$ & A.C. impedance & {$[34]$} \\
& $0.01-100 \mathrm{ng} / \mathrm{mL}$ & $1.64 \mathrm{pg} / \mathrm{mL}$ & DPV & {$[35]$} \\
\end{tabular}

\subsection{Selectivity, Reproducibility, and Stability of Immunosensors}

In order to evaluate the selectivity of the immunosensor, several interfering compounds that may exist in the human environment were introduced, including L-cysteine, AFP, glucose, L-glutamine, vitamin $C$, and human serum. This immunosensor was incubated with $10 \mathrm{ng} / \mathrm{mL}$ CEA containing one of the above-mentioned compounds $(100 \mathrm{ng} / \mathrm{mL})$, respectively, as shown in Figure 6, where A is pure CEA without interference, and B, C, D, E, F, and G are mixtures of CEA and L-cysteine, AFP, glucose, L-glutamine, vitamin $C$, and human serum, respectively. The change in current caused by the interfering compound was less than $5.4 \%$ compared to no interference, indicating that the immunosensor had good selectivity.

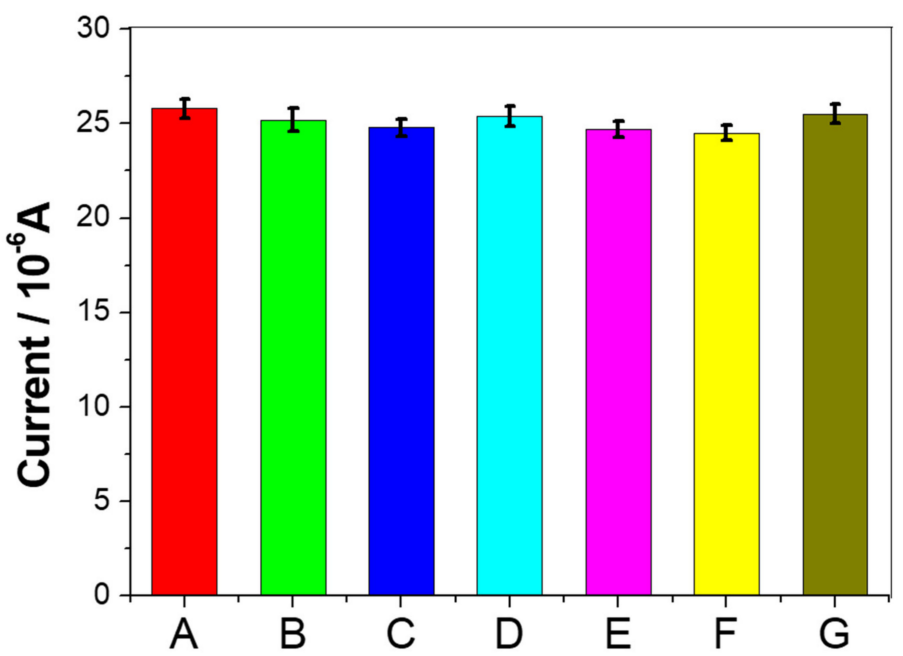

Figure 6. Study of the specificity of the immunosensor towards various interfering compounds. (A) $10 \mathrm{ng} / \mathrm{mL} \mathrm{CEA;} \mathrm{(B)} 10 \mathrm{ng} / \mathrm{mL}$ CEA + $100 \mathrm{ng} / \mathrm{mL}$ L-cysteine; (C) $10 \mathrm{ng} / \mathrm{mL}$ CEA + $100 \mathrm{ng} / \mathrm{mL}$ AFP; (D) $10 \mathrm{ng} / \mathrm{mL}$ CEA + $100 \mathrm{ng} / \mathrm{mL}$ glucose; (E) $10 \mathrm{ng} / \mathrm{mL}$ CEA + $100 \mathrm{ng} / \mathrm{mL}$ L-glutamine; (F) $10 \mathrm{ng} / \mathrm{mL}$ $\mathrm{CEA}+100 \mathrm{ng} / \mathrm{mL}$ vitamin C; (G) $10 \mathrm{ng} / \mathrm{mL}$ CEA + $100 \mathrm{ng} / \mathrm{mL}$ human serum. Error bars represent the standard deviation, $n=5$. 
Reproducibility is an important indicator for evaluating the performance of immunosensors. Five immunosensors were repeatedly prepared by the same method for measuring $10 \mathrm{ng} / \mathrm{mL}$ CEA. The relative standard deviation of the peak current obtained was $5.1 \%$, indicating that the sensor had good reproducibility. In addition, the stability of the immunosensor was studied by keeping the immunosensor in the PBS solution ( $\mathrm{pH} 7.4$ ) at $4{ }^{\circ} \mathrm{C}$ for 2 weeks. It was found that the immunosensor could retain $96 \%$ of the original electrochemical signal strength. The results indicate that the immunosensor had good stability.

\subsection{Real Sample Analyses}

In order to evaluate the practical application of the proposed immunosensor in the detection of CEA in biological samples, the standard addition method was applied. For this purpose, $30 \mu \mathrm{L}$ of human serum was diluted to $3.0 \mathrm{~mL}$ with PBS. Firstly, different amounts of CEA were added to the $1 \mathrm{~mL}$ vessel, then the above diluted samples were added for further detection. Table 2 shows the analytical results and recoveries. The recoveries of the spiked samples varied in the range of 94.20-107\%. The relative standard deviation (RSD) was obtained in the range of $1.62-2.86 \%$. It was clear that the fabricated immunosensor had significant potential for detecting CEA in real serum samples.

Table 2. Detection of CEA in human serum samples.

\begin{tabular}{ccccc}
\hline Samples & $\begin{array}{c}\text { Added } \\
(\mathbf{n g} / \mathbf{m L})\end{array}$ & $\begin{array}{c}\text { Found } \\
(\mathbf{n g} / \mathbf{m L})\end{array}$ & Recovery (\%) & RSD (\%) \\
\hline 1 & 0.10 & 0.107 & 107.00 & 2.86 \\
2 & 1.00 & 0.942 & 94.20 & 2.33 \\
3 & 10.00 & 10.480 & 104.80 & 1.62 \\
\hline
\end{tabular}

\section{Conclusions}

In this study, a new type of CEA electrochemical immunosensor was constructed using $\mathrm{Pt}$ nanoparticles and HGO. The sensing interface of the sensor combined the advantages of nanoplatinum and porous graphene, and had a large specific surface area, excellent electrical conductivity, biocompatibility, and good catalysis, which not only greatly increased the fixed amount of biomolecules, but also significantly improved sensor sensitivity and stability. The electrochemical immunosensor based on 3DPt/HGO composites was used to detect CEA, with a wide response range of $0.001 \mathrm{ng} / \mathrm{mL}$ to $150 \mathrm{ng} / \mathrm{mL}$ and a lower detection limit of $0.0006 \mathrm{ng} / \mathrm{mL}$, which provides a new method for the detection of CEA. The immunosensor has the advantages of simple manufacture, convenient use, low cost, and has potential application value in biomedicine, clinical diagnosis, health detection, and more.

Author Contributions: Conceptualization, A.J. and G.L.; methodology, G.L.; formal analysis, Q.X.; investigation, A.J.; data curation, W.F.; writing-A.J.; writing-Q.X.; funding acquisition, G.L. All authors have read and agreed to the published version of the manuscript.

Funding: This research was funded by the National Natural Science Foundation of China (U1404824 and 81741147), Henan International Cooperation in Science and Technology (172102410083), the Natural Science Foundation of Henan Province (182300410270), and the Innovation Scientists and Technicians Troop Construction Projects of Henan Province.

Conflicts of Interest: The authors declare no conflicts of interest.

\section{References}

1. Turkyilmaz, A.; Eroglu, A.; Aydin, Y.; Karaoglanoglu, N. The relationship of serum CEA and CA 19-9 levels to liver metastasis and pancreatic invasion in esophageal cancer. Turk. J. Med. Sci. 2009, 39, 895-899.

2. Van Manen, L.; Groen, J.V.; Putter, H.; Vahrmeijer, A.L.; Swijnenburg, R.-J.; Bonsing, B.A.; Mieog, J.S.D. Elevated CEA and CA19-9 serum levels independently predict advanced pancreatic cancer at diagnosis. Biomarkers 2020, 25, 186-193. [CrossRef] [PubMed] 
3. Amri, R.; Berger, D.L. Elevation of Pretreatment Carcinoembryonic Antigen Level as a Prognostic Factor for Colon Cancer Incorporating a C Stage in the AJCC TNM Classification. JAMA Surg. 2015, 150, 755-756. [CrossRef] [PubMed]

4. Liang, G.; Zhu, Y.; Ali, D.J.; Tian, T.; Xu, H.; Si, K.; Sun, B.; Chen, B.; Xiao, Z. Engineered exosomes for targeted co-delivery of miR-21 inhibitor and chemotherapeutics to reverse drug resistance in colon cancer. J. Nanobiotechnology 2020, 18, 10-24. [CrossRef] [PubMed]

5. Maccio, G.; Goussot, V.; Berriolo-Riedinger, A.; Riedinger, J.-M. Clinical value of CEA for detection of distant metastases in newly diagnosed breast cancer: Comparison with CA 15-3. Annales De Biologie Clinique 2017, 75, 431-441. [CrossRef] [PubMed]

6. Tang, Z.; Li, L.; Shen, L.; Shen, X.; Ju, S.; Cong, H. Diagnostic Value of Serum Concentration and Integrity of Circulating Cell-Free DNA in Breast Cancer: A Comparative Study With CEA and CA 15-3. Lab. Med. 2018, 49, 323-328. [CrossRef]

7. Zhao, W.; Yu, H.; Han, Z.; Gao, N.; Xue, J.; Wang, Y. Clinical significance of joint detection of serum CEA, SCCA, and bFGF in the diagnosis of lung cancer. Int. J. Clin. Exp. Pathol. 2015, 8, 9506-9511.

8. Wu, L.-X.; Li, X.-F.; Chen, H.-F.; Zhu, Y.-C.; Wang, W.-X.; Xu, C.-W.; Xie, D.-F.; Wan, Y.; Du, K.-Q. Combined detection of CEA and CA125 for the diagnosis for lung cancer: A meta-analysis. Cell. Mol. Biol. 2018, 64, 67-70. [CrossRef]

9. Lee, E.-C.; Yang, J.-Y.; Lee, K.-G.; Oh, S.-Y.; Suh, Y.-S.; Kong, S.-H.; Yang, H.-K.; Lee, H.-J. The value of postoperative serum carcinoembryonic antigen and carbohydrate antigen 19-9 levels for the early detection of gastric cancer recurrence after curative resection. J. Gastric Cancer 2014, 14, 221-228. [CrossRef]

10. Gong, X.; Zhang, H. Diagnostic and prognostic values of anti-helicobacter pylori antibody combined with serum CA724, CA19-9, and CEA for young patients with early gastric cancer. J. Clin. Lab. Anal. 2020, 4, 1-8. [CrossRef]

11. Tao, Z.; Du, J.; Cheng, Y.; Li, Q. Electrochemical Immune Analysis System for Gastric Cancer Biomarker Carcinoembryonic Antigen (CEA) Detection. Int. J. Electrochem. Sci. 2018, 13, 1413-1422. [CrossRef]

12. Khoo, S.K.; Mackay, E.V. Carcinoembryonic antigen by radioimmunoassay in the detection of recurrence during long-term followup of female genital cancer. Cancer 1974, 34, 542-548. [CrossRef]

13. Jiang, J.; Zhao, S.; Huang, Y.; Qin, G.; Ye, F. Highly sensitive immunoassay of carcinoembryonic antigen by capillary electrophoresis with gold nanoparticles amplified chemiluminescence detection. J. Chromatogr. A 2013, 1282, 161-166. [CrossRef] [PubMed]

14. Zhou, M.-Q.; Du, Y.; Liu, Y.-W.; Wang, Y.-Z.; He, Y.-Q.; Yang, C.-X.; Wang, W.-J.; Gao, F. Clinical and experimental studies regarding the expression and diagnostic value of carcinoembryonic antigen-related cell adhesion molecule 1 in non-small-cell lung cancer. BMC Cancer 2013, 13, 359-368. [CrossRef]

15. Wu, M.; Zhao, C.L.; Yang, Y.X.; Cao, K.H.; Qiao, X.W.; Hong, C.L. Ag-Co3O4 @ Nr GO Material Synthesized by One-pot Hydrothermal Method for Carcinoembryonic Antigen (CEA) Detection of Enzyme-mimetic Electrochemical Immunosensor. Electroanalysis 2020, 32, 1329-1336. [CrossRef]

16. Shi, W.T.; Ma, Z.F. A novel label-free amperometric immunosensor for carcinoembryonic antigen based on redox membrane. Biosens. Bioelectron. 2011, 26, 3068-3071. [CrossRef]

17. Yang, Y.; Jiang, M.; Cao, K.; Wu, M.; Zhao, C.; Li, H.; Hong, C. An electrochemical immunosensor for CEA detection based on Au-Ag/rGO@PDA nanocomposites as integrated double signal amplification strategy. Microchem. J. 2019, 151, 104223-104230. [CrossRef]

18. Tian, J.N.; Zhou, L.J.; Zhao, Y.C.; Wang, Y.; Peng, Y.; Zhao, S.L. Multiplexed detection of tumor markers with multicolor quantum dots based on fluorescence polarization immunoassay. Talanta 2012, 92, 72-77. [CrossRef]

19. Zheng, X.; Mo, G.; He, Y.; Qin, D.; Jiang, X.; Mo, W.; Deng, B. An electrochemiluminescence immunosensor based on ZnSe@ZnS QDs composite for CEA detection in human serum. J. Electroanal. Chem. 2019, 844, 132-141. [CrossRef]

20. Lv, H.; Li, Y.; Zhang, X.; Gao, Z.; Zhang, C.; Zhang, S.; Dong, Y. Enhanced peroxidase-like properties of $\mathrm{Au} @ \mathrm{Pt} \mathrm{DNs} / \mathrm{NG} / \mathrm{Cu} 2+$ and application of sandwich-type electrochemical immunosensor for highly sensitive detection of CEA. Biosens. Bioelectron. 2018, 112, 1-7. [CrossRef]

21. Zhang, C.; Zhang, S.; Jia, Y.; Li, Y.; Wang, P.; Liu, Q.; Xu, Z.; Li, X.; Dong, Y. Sandwich-type electrochemical immunosensor for sensitive detection of CEA based on the enhanced effects of Ag NPs@CS spaced Hemin/rGO. Biosens. Bioelectron. 2019, 126, 785-791. [CrossRef] [PubMed] 
22. Tian, L.; Liu, L.; Li, Y.; Wei, Q.; Cao, W. Ultrasensitive sandwich-type electrochemical immunosensor based on trimetallic nanocomposite signal amplification strategy for the ultrasensitive detection of CEA. Sci. Rep. 2016, 6, 30849-30856. [CrossRef] [PubMed]

23. Wang, Y.; Wang, Y.; Wu, D.; Ma, H.; Zhang, Y.; Fan, D.; Pang, X.; Du, B.; Wei, Q. Label-free electrochemical immunosensor based on flower-like Ag/MoS2/rGO nanocomposites for ultrasensitive detection of carcinoembryonic antigen. Sens. Actuators B-Chem. 2018, 255, 125-132. [CrossRef]

24. Liu, Y.; Li, T.; Ling, C.; Chen, Z.; Deng, Y.; He, N. Electrochemical sensor for Cd2+ and Pb2+ detection based on nano-porous pseudo carbon paste electrode. Chin. Chem. Lett. 2019, 30, 2211-2215. [CrossRef]

25. Karim, M.R.; Hatakeyama, K.; Matsui, T.; Takehira, H.; Taniguchi, T.; Koinuma, M.; Matsumoto, Y.; Akutagawa, T.; Nakamura, T.; Noro, S.-I.; et al. Graphene Oxide Nanosheet with High Proton Conductivity. J. Am. Chem. Soc. 2013, 135, 8097-8100. [CrossRef]

26. Fugallo, G.; Cepellotti, A.; Paulatto, L.; Lazzeri, M.; Marzari, N.; Mauri, F. Thermal Conductivity of Graphene and Graphite: Collective Excitations and Mean Free Paths. Nano Lett. 2014, 14, 6109-6114. [CrossRef]

27. Jing, A.; Liang, G.; Shi, H.; Yuan, Y.; Zhan, Q.; Feng, W. Three-Dimensional Holey-Graphene Architectures for Highly Sensitive Enzymatic Electrochemical Determination of Hydrogen Peroxide. J. Nanosci. Nanotechnol. 2019, 19, 7404-7409. [CrossRef]

28. Sheng, Y.; Miao, H.; Jing, J.; Yao, W.; Zhu, Y. Perylene diimide anchored graphene 3D structure via pi-pi interaction for enhanced photoelectrochemical degradation performances. Appl. Catal. B-Environ. 2020, 272, 118897-118902. [CrossRef]

29. Xu, Y.; Chen, C.Y.; Zhao, Z.; Lin, Z.; Lee, C.; Xu, X.; Wang, C.; Huang, Y.; Shakir, M.I.; Duan, X. Solution Processable Holey Graphene Oxide and Its Derived Macrostructures for High-Performance Supercapacitors. Nano Lett. 2015, 15, 4605. [CrossRef]

30. Jing, A.; Liang, G.; Yuan, Y.; Feng, W. Three-Dimensional Au/Holey-Graphene as Efficient Electrochemical Interface for Simultaneous Determination of Ascorbic Acid, Dopamine and Uric Acid. Micromachines 2019, 10, 84. [CrossRef]

31. Uzundurukan, A.; Devrim, Y. Carbon nanotube-graphene hybrid supported platinum as an effective catalyst for hydrogen generation from hydrolysis of ammonia borane. Int. J. Hydrog. Energy 2019, 44, 26773-26782. [CrossRef]

32. Wang, X.; Shang, L.; Zhang, W.; Jia, L.P.; Ma, R.N.; Jia, W.L.; Wang, H.S. An ultrasensitive luminol cathodic electrochemiluminescence probe with highly porous $\mathrm{Pt}$ on ionic liquid functionalized graphene film as platform for carcinoembryonic antigen sensing. Biosens. Bioelectron. 2019, 141, 111436-111443. [CrossRef] [PubMed]

33. Yang, Y.Y.; Liu, Q.; Liu, Y.; Cui, J.J.; Liu, H.; Wang, P.; Li, Y.Y.; Chen, L.; Zhao, Z.D.; Dong, Y.H. A novel label-free electrochemical immunosensor based on functionalized nitrogen-doped graphene quantum dots for carcinoembryonic antigen detection. Biosens. Bioelectron. 2017, 90, 31-38. [CrossRef] [PubMed]

34. Liu, N.; Feng, F.; Liu, Z.M.; Ma, Z.F. Porous platinum nanoparticles and PdPt nanocages for use in an ultrasensitive immunoelectrode for the simultaneous determination of the tumor markers CEA and AFP. Microchim. Acta 2015, 182, 1143-1151. [CrossRef]

35. Jia, X.L.; Chen, X.; Han, J.M.; Ma, J.; Ma, Z.F. Triple signal amplification using gold nanoparticles, bienzyme and platinum nanoparticles functionalized graphene as enhancers for simultaneous multiple electrochemical immunoassay. Biosens. Bioelectron. 2014, 53, 65-70. [CrossRef]

36. Chen, Y.; Wang, A.-J.; Yuan, P.-X.; Luo, X.; Xue, Y.; Feng, J.-J. Three dimensional sea-urchin-like PdAuCu nanocrystals/ferrocene-grafted-polylysine as an efficient probe to amplify the electrochemical signals for ultrasensitive immunoassay of carcinoembryonic antigen. Biosens. Bioelectron. 2019, 132, 294-301. [CrossRef] [PubMed]

37. Zhang, L.; Shi, G. Preparation of Highly Conductive Graphene Hydrogels for Fabricating Supercapacitors with High Rate Capability. J. Phys. Chem. C 2011, 115, 17206-17212. [CrossRef]

38. Yang, M.-Q.; Pan, X.; Zhang, N.; Xu, Y.-J. A facile one-step way to anchor noble metal (Au, Ag, Pd) nanoparticles on a reduced graphene oxide mat with catalytic activity for selective reduction of nitroaromatic compounds. Crystengcomm 2013, 15, 6819-6828. [CrossRef]

39. Ji, X.; Song, X.; Li, J.; Bai, Y.; Yang, W.; Peng, X. Size control of gold nanocrystals in citrate reduction: The third role of citrate. J. Am. Chem. Soc. 2007, 129, 13939-13948. [CrossRef] [PubMed] 
40. Huang, Z.-N.; Zou, J.; Teng, J.; Liu, Q.; Yuan, M.-M.; Jiao, F.-P.; Jiang, X.-Y.; Yu, J.-G. A novel electrochemical sensor based on self-assembled platinum nanochains-Multi-walled carbon nanotubes-graphene nanoparticles composite for simultaneous determination of dopamine and ascorbic acid. Ecotoxicol. Environ. Saf. 2019, 172, 167-175. [CrossRef] [PubMed]

41. Yang, G.; Cao, J.; Li, L.; Rana, R.K.; Zhu, J.-J. Carboxymethyl chitosan-functionalized graphene for label-free electrochemical cytosensing. Carbon 2013, 51, 124-133. [CrossRef]

42. Jiang, Y.; Zhang, X.; Pei, L.; Yue, S.; Ma, L.; Zhou, L.; Huang, Z.; He, Y.; Gao, J. Silver nanoparticles modified two-dimensional transition metal carbides as nanocarriers to fabricate acetycholinesterase-based electrochemical biosensor. Chem. Eng. J. 2018, 339, 547-556. [CrossRef]

43. Cui, Z.; Wu, D.; Zhang, Y.; Ma, H.; Li, H.; Du, B.; Wei, Q.; Ju, H. Ultrasensitive electrochemical immunosensors for multiplexed determination using mesoporous platinum nanoparticles as nonenzymatic labels. Anal. Chim. Acta 2014, 807, 44-50. [CrossRef] [PubMed]

44. Akbari Nakhjavani, S.; Afsharan, H.; Khalilzadeh, B.; Ghahremani, M.H.; Carrara, S.; Omidi, Y. Gold and silver bio/nano-hybrids-based electrochemical immunosensor for ultrasensitive detection of carcinoembryonic antigen. Biosens. Bioelectron. 2019, 141, 111439. [CrossRef] [PubMed]

(C) 2020 by the authors. Licensee MDPI, Basel, Switzerland. This article is an open access article distributed under the terms and conditions of the Creative Commons Attribution (CC BY) license (http://creativecommons.org/licenses/by/4.0/). 